\title{
Regional Disparity in Urbanizing China: Empirical Study of Unbalanced Development Phenomenon of Towns in Southwest China
}

DOI:

10.1061/(ASCE)UP.1943-5444.0000586

\section{Document Version}

Final published version

Link to publication record in Manchester Research Explorer

Citation for published version (APA):

Xiong, N., Wong, S. W., Ren, Y., \& shen, L. (2020). Regional Disparity in Urbanizing China: Empirical Study of Unbalanced Development Phenomenon of Towns in Southwest China. Journal of Urban Planning and Development. https://doi.org/10.1061/(ASCE)UP.1943-5444.0000586

\section{Published in:}

Journal of Urban Planning and Development

\section{Citing this paper}

Please note that where the full-text provided on Manchester Research Explorer is the Author Accepted Manuscript or Proof version this may differ from the final Published version. If citing, it is advised that you check and use the publisher's definitive version.

\section{General rights}

Copyright and moral rights for the publications made accessible in the Research Explorer are retained by the authors and/or other copyright owners and it is a condition of accessing publications that users recognise and abide by the legal requirements associated with these rights.

\section{Takedown policy}

If you believe that this document breaches copyright please refer to the University of Manchester's Takedown Procedures [http://man.ac.uk/04Y6Bo] or contact uml.scholarlycommunications@manchester.ac.uk providing relevant details, so we can investigate your claim.

\section{OPEN ACCESS}




\title{
Regional Disparity in Urbanizing China: Empirical Study of Unbalanced Development Phenomenon of Towns in Southwest China
}

\author{
Ning Xiong ${ }^{1}$; Siu Wai Wong ${ }^{2}$; Yitian Ren ${ }^{3}$; and Liyin Shen ${ }^{4}$
}

\begin{abstract}
Development for townships is an important driving force for new-type urbanization of China. However, it appears that the level of the development between different towns is severely unbalanced. This unbalanced development phenomenon has resulted in various problems such as poor living environment and brain drain in less developed towns. This paper introduces a framework for examining the unbalanced development phenomenon between towns. By using the framework, the degree of unbalanced development between towns in the Southwest region of China has been investigated, and the reasons contributing to the unbalanced phenomenon are discussed in depth. Indicators for examining the level of township development are selected from three dimensions, namely, development scale, economic development level, and social development level. The data applied for analysis are collected from 16 sample towns in Southwest China. Research methods of PCA and TOPSIS are employed collectively to assist the analysis. The parameter of variable coefficient is used to measure the degree of unbalanced development between towns. Onsite surveys as well as in-depth semistructured interviews are conducted in these sample towns to support the discussions on the analysis results. The findings indicate that the unbalanced development between towns in Southwest China is very significant in economic standard and development scales, whilst the social development is reasonably balanced. Various contributing reasons for the unbalanced development phenomenon are analyzed, and it is suggested that policy-related factors have a key influence. Research findings provide government departments with valuable references to implement effective policy measures for promoting balanced development between towns in the urbanizing China. DOI: 10.1061/(ASCE)UP.1943-5444.0000586. (C) 2020 American Society of Civil Engineers.
\end{abstract}

Author keywords: Township development; Unbalanced development; Urbanization; Southwest China; Mountainous townships; PCA; TOPSIS.

\section{Introduction}

Township plays a vital role in urbanization development in China. In March 2014, the National Council of China implemented the New-Type Urbanization Plan (2014-2020) as an important national policy. In this plan, the development of towns is considered to be a key indicator for the mission of urbanization. It highlights

${ }^{1}$ Research Assistant, Dept. of Building and Real Estate, Hong Kong Polytechnic Univ., Hung Hom, Kowloon 999077, Hong Kong; Ph.D. Student, Dept. of Geography, Univ. of Utah, 260 S Central Campus Dr., Salt Lake City, UT 84112. Email: ning.xiong@utah.edu

${ }^{2}$ Assistant Professor, Dept. of Building and Real Estate, Hong Kong Polytechnic Univ., Hung Hom, Kowloon 999077, Hong Kong. Email: ivy.sw.wong@polyu.edu.hk

${ }^{3}$ Research Assistant, School of Management Science and Real Estate, Chongqing Univ., Shazheng St., Chongqing 400045, China; International Research Center for Sustainable Built Environment, Chongqing Univ., Shazheng St., Chongqing 400045, China; Ph.D. Student, Dept. of Planning and Environmental Management, Univ. of Manchester, Manchester, Oxford Rd., Manchester M13 9PL, UK. ORCID: https://orcid.org/0000 -0003-1638-5534. Email: yitian.ren@postgrad.manchester.ac.uk

${ }^{4}$ Professor, School of Management Science and Real Estate, Chongqing Univ., Shazheng St., Chongqing 400045, China; International Research Center for Sustainable Built Environment, Chongqing Univ., Shazheng Street, Chongqing 400045, China (corresponding author). Email: shenliyin@cqu.edu.cn

Note. This manuscript was submitted on February 25, 2019; approved on December 17, 2019; published online on May 22, 2020. Discussion period open until October 22, 2020; separate discussions must be submitted for individual papers. This paper is part of the Journal of Urban Planning and Development, (C) ASCE, ISSN 0733-9488. the importance of the strategic position of developing towns in the development of new-type urbanization. Township is the bottom-layer of government in the administration hierarchy in China, and serves as the connection and transfer station between urban and rural areas. It is appreciated that the development of towns can contribute to narrowing the development gap or difference between urban and rural areas by improving living standards in rural areas (Gu et al. 2015; Liu and Li 2017; Shi 2002). On the other hand, a well-developed town can attract population in-flows and provide a buffer to the population flows to cities, thus "urban diseases" such as congested traffic and air pollution can be mitigated (Cao et al. 2014; Gu et al. 2015; Liang 2009; Qian and Xue 2017; Song and Li 2015). Other typical benefits from developing townships include the promotion of urban-rural integration, the increase of domestic demand for economic activities, and the growth of in-situ urbanization (Lin and Ma 1994; Shen et al. 2018; Tan 1986).

The Southwest region in China, which commonly refers to Sichuan province, Chongqing municipal city, Guizhou province, and Yunnan province, has mountainous areas that cover more than $85 \%$ of the region. The development of these mountainous areas in Southwest China is constrained by topography, ecological environment, and economic and social background, and the level of development in these areas severely lags behind in comparison with that in the plain areas. There are a great number of towns in the Southwestern mountainous areas that are traditionally less developed and characterized with abundant natural resources, many ethnic minorities and cultures, and a fragile ecological environment. Nevertheless, the development of these mountainous towns 
is strategically important in promoting urban-rural integration and sustainable urbanization in China. The Chinese government has implemented various policies and invested a large amount of resources for promoting the development of these areas. According to the China urban-rural construction statistical yearbook, RMB1250.87 million was invested in 2015 for infrastructure construction in the Southwest mountainous townships in China. The implementation of these policies and investment measures have brought significant progress in promoting the development of these townships.

Nevertheless, the difference in development between these mountainous towns remains significant. In other words, the development level between different mountainous towns is unbalanced. For example, according to Xu et al. (2013), 50\% of the township GDP in Chongqing is contributed by only $20 \%$ of towns, indicating that the economic development level between the towns in Chongqing is significantly unbalanced. The presence of an unbalanced town development phenomenon has brought with it many problems, such as a large floating population and numerous hollow villages with many left-behind children and elderly people remaining in these less developed towns. These problems have resulted in various negative social consequences, such as lack of care for aging people or provision for left-behind children's education (Long et al. 2012). These problems cannot be solved if the reasons contributing to the unbalanced phenomenon are not properly understood and addressed. Therefore, it is essential to understand the reasons behind the unbalanced development between towns.

In fact, there has been a long-lasting debate about balanced and unbalanced development in academia. Nurkse's vicious circle of poverty and Myrdal's cumulative causation mode explain a balanced development and argue that the development process is self-reinforcing and the unbalanced rate increases over time (Nurkse 1953; Myrdal 1957). However, Hirschman argued the advantage of maintaining an unbalanced development strategy, and suggested giving priority to the development of regions with greater growth momentum so that other regions can be promoted though diffusion effects (Hirschman 1958). Similarly, the principle of growth poles introduced by Perroux (1950), inverted-U model by Williamson (1965), and the stage theory for describing economic growth by Rostow (1956) all argue that the degree of unbalanced development increases in the early development and then begins to fall in line with the maturity of economic development. These two development strategies have been constantly tested, challenged, and enriched in different areas (Barro and Sala-I-Martin 1992; Broadberry and Gupta 2006; Friedmann 1986; He et al. 2017; Li and Wei 2010; Litwack and Qian 1998; Ke and Feser 2010; Krugman 1999; Silva 2007; Wei et al. 2017). Although many studies have contributed to the antidotes to the conflicts embodied in unbalanced development, agreement has not yet been reached (Wei 2015).

The emergence of an unbalanced development phenomenon between regions in a country will generally attract governmental attention as it is usually associated with political stability and social cohesion (Kanbur and Venables 2005). For example, China has been experiencing unbalanced development between regions, particularly in the last three decades. With the aim of mitigating the adverse impacts of unbalanced development between regions, a series of policy measures and strategies has been implemented by the Chinese government, for example, the Western Development Strategy in 1999, Reviving Northeastern Region in 2003, Promoting the Rise of Central China Plan in 2004, Development Strategy of Yangtze River Economic Belt in 2014. Furthermore, the report of the 19th Chinese National Congress in 2017 introduces a national policy implementing regional coordinated development strategy. The strategy emphasizes promoting the coordinated development between cities and towns to achieve a better balance of status between the income distribution and the population distribution spatially. All the previously discussed national policies indicate that the Chinese government is in favor of promoting balanced development between towns in the current development stage of the country by implementing various policy measures.

There are various existing studies about the development of townships in China. A number of research works have examined the policy effects on the development of these Towns and Village Enterprises (TVEs) in the Pearl River Delta and other coastal regions. Their research findings demonstrate that the development of these towns is largely driven by the special policies granted by central government. The geographical adjacency to Hong Kong and Macao is also an advantage contributing to the development in these towns (Bellandi and Di Tommaso 2005; Liu and Li 2019; Ma and Lin 1993; Qian et al. 2012; Shen et al. 2006; Shen et al. 2002; Wong et al. 2003; Yang and Liao 2010). Other studies argue that town development in the Yangtze River Delta is also the result of taking advantage of the well-established traditional handicraft industries and the radiation of the developed industries in large cities such as Shanghai and Nanjing (Ma and Fan 1994; Wang 1999; Wong et al. 2003).

There are several studies investigating the phenomenon of unbalanced development between towns from different regions of China. For example, Yuan and Yang (2004) found that a significant difference exists in the development level between towns located in the eastern, central and western regions of China. They suggested that towns in Eastern China have much better economic growth rates, industrial structure, and investment structure. In examining the small towns in Jiangsu province in China, Ma et al. (2004) demonstrated the obvious unbalanced phenomenon in development between towns in terms of township scale and economic standards. In examining the unbalanced phenomenon between small towns in Changchun and Jilin, Zhang et al. (2011) found significant differences between towns in economic development level and urbanization growth. However, whilst these studies presented the unbalanced phenomenon in development between towns, they have not investigated the reasons contributing to this unbalanced phenomenon.

Research works have also been undertaken in towns in the western regions of China, which mainly focus on the identification of problems affecting the town development in these regions and the countermeasures for solving the problems. For example, they reported the main challenges faced by the mountainous towns in Western China include poor economy and the responsibility imposed for protecting ecological environment (Lu and Qian 2007; Mao and Zhang 2009). However, such challenges are addressed indiscriminately without considering the phenomenon of unbalanced development between the towns in these regions. Other scholars have proposed measures to improve the development level of towns in mountainous areas. For example, Yao and Xie (2016) suggested transforming the traditional development model, adjusting the structure for economic products, improving the planning layout of towns to protect cultural and humanistic characteristics. Zhang et al. (2013) proposed measures for preventing soil erosion of townships in mountainous area. Zhang et al. (2015) and Hao et al. (2015) proposed measures for reducing the effects of earthquake disasters in affected towns. There are still other studies investigating various measures to help townships in China to develop. Nevertheless, these measures are proposed as general solutions without incorporating the effects of the unbalanced phenomenon between towns. 
In fact, the unbalanced development between towns has a significant effect on the design and selection of development measures. Previous research works are limited to providing methods for understanding the unbalanced phenomenon between the mountainous towns in underdeveloped regions such as Southwest China. This paper therefore aims to establish a framework to measure the unbalanced degree of development between the towns in the mountainous area of Southwest China, and to examine the specific reasons contributing to this unbalanced phenomenon. The rest of the paper is designed as follows. The next section presents the research methods; the section Research Data describes the research data employed for analysis; the section Data Analysis shows analysis results; the section Reasons Contributing to the Unbalanced Development Phenomenon discusses the reasons contributing to unbalanced phenomenon in the surveyed area; and the section Conclusions provides the conclusions of this study.

\section{Research Methods}

The following research methods were adopted to conduct this study. First, a comprehensive literature review was conducted to select appropriate indicators for measuring the development level for individual towns. The validity of the indicators were tested through interview surveys. Second, the principal component analysis (PCA) method and the technique for order preference by similarity to ideal solution (TOPSIS) were used jointly to evaluate the development level of a sample of individual towns. Third, a variable coefficient was used to measure the degree of unbalanced development between the surveyed towns by incorporating the results from the TOPSIS analysis. Finally, field surveys and in-depth semistructured interviews with officials who work in the sample towns were conducted in order to analyze the reasons contributing to the unbalanced development phenomenon.

\section{PCA Method}

Previous studies suggest that PCA is an effective approach for generating a set of independent principal components to represent the original list of indicators and to determine weighting values between these independent principal components (Jolliffe 2011). It is recognized that the PCA method is not only able to solve the problem of information overlaps between the indicators, but also able to simplify the indicator structure (Wold et al. 1987). In addition, by using PCA, the weighting values between the principal components are not determined subjectively, which helps filter the subjective influence (Dyer 1990). In this study, the PCA method was used to obtain the value of $W_{P}$ which is the weighting value of principal component $P$, and the value of $F_{P i}$ which is the principle component score of the sample town $i$ for the principal component $P$. The calculation process for $W_{P}$ and $F_{P i}$ is assisted by using software package SPSS 22.0.

\section{TOPSIS Technique}

TOPSIS technique was used in this study to evaluate the development level of individual sample towns. This evaluation technique was first introduced by Hwang and Yoon (1981) and has become one of the most widely adopted evaluation methods in various research domains. According to the principle of TOPSIS, evaluation objects (sample towns in our study) are ranked according to their distance from the positive ideal solution (PIS) and the negative ideal solution (NIS). Specifically, PIS represents a solution that maximizes the benefit criteria and minimizes the cost criteria, while NIS maximizes the cost criteria and minimizes the benefit criteria (Wang and Lee 2007). The TOPSIS method takes into account both PIS and NIS distances. Evaluation objects are ranked is according to their relative similarity to the ideal solution. The optimal object is defined as the one closest to PIS and the farthest from NIS in geometric terms (Ertuğrul and Karakașoğlu 2009). The procedures of using TOPSIS are summarized as follows.

- Step 1: To construct a weighted normalized matrix, denoted by $Z$

$$
\left[\begin{array}{ccc}
Z_{11} & \cdots & Z_{P 1} \\
\vdots & \ddots & \vdots \\
Z_{1 i} & \cdots & Z_{P i}
\end{array}\right]
$$

where the element $Z_{P i}=W_{P} \times F_{P i}, i=$ evaluation object (namely, sample towns in this study); $P=$ principal component; where $F_{P i}=$ principal component score of the sample town, $i=$ principal component $P$; and $W_{P}=$ weighting value of the principal component $P$.

- Step 2: To determine the PIS and NIS for each principal component, the PIS and NIS, denoted by $Z_{P}^{+}$and $Z_{P}^{-}$respectively, are defined as

$$
Z_{P}^{+}=\max _{i}\left(Z_{P i}\right), Z_{P}^{-}=\min _{i}\left(Z_{P i}\right)
$$

- Step 3: To calculate the distances of each evaluation object (sample town $i$ ) from PIS and NIS respectively, denoted by $D_{i}^{+}$and $D_{i}^{-}$, by using the following:

$$
D_{i}^{+}=\sqrt{\sum_{1}^{P}\left(Z_{P i}-Z_{P}^{+}\right)^{2}}, D_{i}^{-}=\sqrt{\sum_{1}^{P}\left(Z_{P i}-Z_{P}^{-}\right)^{2}}
$$

- Step 4: To obtain the ranking order of each evaluation object (sample town $i$ ) according to the value of the closeness coefficient. The closeness coefficient for each sample town $i$, donated by $C_{i}$, will be calculated as

$$
C_{i}=\frac{D_{i}^{-}}{D_{i}^{-}+D_{i}^{+}},\left(0<C_{i}<1\right)
$$

The greater the value of the closeness coefficient $C_{i}$, the better the performance of the evaluation object $i$ (sample town $i$ ). Accordingly, the ranking between the sample towns can be generated.

\section{Variable Coefficient}

Variable coefficient is an effective measure for indicating the relative dispersion of a set of data. It is widely used to examine the variance and difference between a set of objects sample towns in this research. Variable coefficient is employed to measure the degree of unbalanced development between towns, which is calculated as

$$
C V\left(C_{i}\right)=\frac{\sigma\left(C_{i}\right)}{\overline{C_{i}}}
$$

where $\overline{C_{i}}=$ average value between closeness coefficients $C_{i}$ for all the sample towns; and $\sigma\left(C_{i}\right)=$ standard deviation of the closeness coefficients $C_{i}$.

\section{Field Surveys and In-Depth Semistructured Interviews}

Field surveys and in-depth semistructured interviews were conducted with the government officials who work in the sample towns in order to analyze the reasons contributing to the unbalanced development between towns. The interviews focused on 




Fig. 1. Spatial distribution of sample towns.

the issues of current development status, challenges faced, selfborne resources, dominant economic activities, suggestions for town development, and any other factors contributing to unbalanced development between towns.

The interviews were conducted from April to October 2016. The interviewed officials included township governors and departmental heads who have rich experience in township management work. Each interview lasted for one to three hours. Since data management systems and the statistics indicators employed are different between towns, only 16 towns could provide effective research data for analysis whilst the research team conducted the interviews in 21 towns. These 16 sample towns include seven in Chongqing municipal city, three in Guizhou province, three in Sichuan province and three in Hubei province, and their distributions are shown in Fig. 1. The three towns in Hubei province are spatially adjacent to Chongqing municipal city and are typical mountainous towns, which are also considered part of the southwest mountainous region in this study. The 16 sample towns are considered representative for this study. They present the mountainous characteristics of towns in Southwest China.

\section{Research Data}

\section{Description of the Sample Towns}

To gain a better understanding of the reasons contributing to the unbalanced development of the 16 sample towns, it was considered necessary to investigate and portray their general information such as resources, advantages, main barriers, current leading industries, and future development orientation. Table 1 summarizes the generalities taken from the field surveys and in-depth semistructured interviews with officials of each sample town. In terms of resources, Table 1 shows that these surveyed towns have unique and abundant resources, including mineral resources, forest resources, cultural resources, ecological resources, agricultural resources, and tourism resources. This implies that these small towns have a good potential to promote local economy by utilizing their self-borne resources. However, with regards to advantages, only a few of them have location advantage or transportation superiority, which indicates that most of these small towns have no location benefits for development. Their transportation facilities are far from developed. In terms of the main barriers to town development, loss of labor-force population and limited financing channels are recognized as typical barriers restraining these townships from development. The discussions during the in-depth semistructured interviews further suggested that the available funds for the construction demands of small mountainous towns in southwestern region of the country is extremely limited and most of funds are from single-channel, namely, the financial budget allocated by the higher-level government. The development of some sample towns is also constrained by environmental protection policies and limited jurisdiction power. In terms of the leading industries, the economy of most sample towns is dominated by agricultural planting and processing industry, and the economy of a few of the sample towns is dominated by tourism or industry. In addition, the industrial structure of most of the surveyed towns is simple with a lack of local characteristics. This portrayed information indicates that these small towns have difficulty in obtaining driving forces to enable the sustainability of economic and social development.

\section{Indicators for Evaluating Development Level of Towns}

The selection for indicators is essential for effective and accurate evaluation of the development level of towns. In this regard, the principle of sustainable development was adopted for indicator selection. In a typical definition in the Brundtland Commission in the report Our Common Future in 1987 (World Commission on Environment and Development 1987), the sustainable development is a particular type of development that has been initially defined as development that meets the needs of the present without compromising the ability of future generations to meet their own needs. This is followed by scholars and practitioners in elaborating the implications of the sustainable development principle from different perspectives, such as an ecological perspective (Forman 1990; 
Table 1. Portray of 16 sample towns summarized from in-depth interviews

\begin{tabular}{|c|c|c|}
\hline Town & Resources and advantages & Main barriers \\
\hline Chaole & $\begin{array}{l}\text { Forest and agricultural resources } \\
\text { Culture heritage resources (Hometown of Chinese } \\
\text { culture) }\end{array}$ & $\begin{array}{l}\text { Loss of labor-force } \\
\text { Low level of management capability } \\
\text { Limited financing channels }\end{array}$ \\
\hline Dalucao & $\begin{array}{l}\text { Forest resources } \\
\text { A national 3A level scenic spots }\end{array}$ & $\begin{array}{l}\text { Loss of labor-force } \\
\text { Limited financing channels } \\
\text { Poor infrastructure } \\
\text { Constrained by environmental } \\
\text { protection policies }\end{array}$ \\
\hline Degan & $\begin{array}{l}\text { An industrial park } \\
\text { Agricultural resources } \\
\text { Location advantage } \\
\text { Transportation superiority }\end{array}$ & Lack of professionals and talents \\
\hline Dingzhai & $\begin{array}{l}\text { Location advantages } \\
\text { Transportation superiority }\end{array}$ & $\begin{array}{l}\text { Loss of labor-force } \\
\text { Lack of professional officials } \\
\text { Low level of management capability }\end{array}$ \\
\hline Fangshan & $\begin{array}{l}\text { A national 3A level scenic spots } \\
\text { Located along the Yangtze River }\end{array}$ & $\begin{array}{l}\text { Loss of labor-force } \\
\text { Limited financing channels } \\
\text { Restriction of jurisdiction power }\end{array}$ \\
\hline Fenshuiling & $\begin{array}{l}\text { Cultural resources } \\
\text { A national agriculture demonstration zone } \\
\text { Transportation superiority }\end{array}$ & $\begin{array}{l}\text { Lack of professionals and talents } \\
\text { Limited financing channels } \\
\text { Restriction of jurisdiction power }\end{array}$ \\
\hline Gaoleshan & An industrial park & Lack of professionals and talents \\
\hline
\end{tabular}

The current leading industries/Future development orientation

Agriculture/Agriculture and tourism

Agriculture/Tourism

Limited financing channels

Agriculture/Tourism

Poor infrastructure

Constrained by environmental

protection policies

Manufacturing industry and agriculture/

Comprehensive

Agriculture/Tertiary industry

Agriculture/Tourism

Agriculture/Tourism

Mineral resources

Forest resources

Location advantage

Transportation superiority

Heishan A national 5A level scenic spots

Agricultural resources

Lushi A national agricultural science and technology

demonstration park

Transportation superiority

Qiantang

Modern economy agriculture

An industrial park

Location advantage

Transportation superiority

Tanghe National history and culture town

Chongqing folk art town

Tangya A world-class heritage

Ecological resources

Tiaodeng A national 3A level scenic spots

An industrial park

Mineral resources

Forestry resources

Location advantage

Yanwo Rich in agricultural resources

Yongxing Provincial historical and cultural towns

China's commercial town

A provincial efficient agricultural demonstration

zone

Location advantage

Transportation superiority

Zhongliangshan Forestry resources

A pollution-free vegetable base

Location advantage

Lack of talents and professional

officials

Limited financing channels

Lack of construction land use quotas

Restriction of jurisdiction power

Limited financing channels

Lack of talents and professionals

Comprehensive/Comprehensive

Tourism/Tourism

Agriculture/Modern agriculture and tourism

Comprehensive/Comprehensive

Loss of labor-force

Limited financing channels

Lack of professionals

Loss of labor-force

Limited financing channels

Constrained by environmental

protection policies

Lack of independent finance power

Restriction of jurisdiction power

Weak capability of public service

Loss of labor-force

Limited financing channels

Lack of talents and professionals

Restriction of jurisdiction power

Limited financing channels

Agriculture/Tourism

Agriculture/Tourism

Industry/Tourism

Agriculture/Agriculture

Agriculture/Agriculture and tertiary industry

Loss of labor-force

Limited financing channels

Restriction on land use policy

Restriction of jurisdiction power

Agriculture/Ecological agriculture and sightseeing 
Goodland and Daly 1996), economic perspective (Barbier 1987; Pearce and Warford 1993), social perspective (Brown 1987; Onishi 1994), and technical perspective (World Resources Institute et al. 1992). The diversity in defining sustainable development is widely appreciated (Robert et al. 2005; Parris and Kates 2003). For example, Giddings et al. (2002) pointed out that sustainable development is an ambiguous conception that can form different derivatives. In general, the principle of sustainable development is defined with three core elements, namely, sustainable economic, social, and environmental development. This three-element principle has been widely adopted although the details of the three elements are described in various ways in the literature.

The appreciation of sustainable urban development has led to growth of various indicator systems for evaluating urban sustainability worldwide. Many indicators have been introduced to evaluate urban sustainability performance (Bossel 1999; Gustavson et al. 1999; Roy 2009). For example, Shen et al. (2011) summarized six international urban sustainability indicator systems proposed by various organizations internationally and regionally. These indicator systems have provided important references which enable countries to tailor their own indicator systems. The Chinese government has also proposed various indicator systems for evaluating urban sustainability. In light of this, Shen and Zhou (2014) identified nine sets of indicator systems produced by different Chinese authority departments which aim to evaluate urban sustainability. Based on the above discussions, this study adopts the references of these six international urban sustainability indicator systems and nine Chinese urban sustainability indicator systems for establishing the candidate indicators to measure the development level of individual towns.

Indicators for measuring small towns should be able to reflect specific regional concerns (Robert et al. 2005). In the context of China, scholars have proposed various indicators in examining the development level of towns (Da et al. 2004; Fan and Xiong 2002; Guo et al. 2014; Huang and Ye 2004; Lu et al. 2001). These indicator systems suggest that to effectively measure the development level of small towns in China, the evaluation of indicator systems should include a scale level of development in addition to economic, social, and environmental dimensions, given the fact that those small-sized towns are limited in achieving industrial agglomeration and promoting the development of the tertiary industry, as echoed by Luo et al. (2000). Therefore, it is well recognized that the development of small towns in the Chinese context should promote scale growth, economic growth, social inclusion, and environmental quality in a dynamic, balanced way. Accordingly, the indicators for measuring the development level of small towns in the Southwest region of China are

Table 2. Typical literature references for establishing indicators

\begin{tabular}{ll}
\hline Authors & \multicolumn{1}{c}{ Literature topic } \\
\hline Lu et al. (2001) & $\begin{array}{l}\text { Study on the system of evaluating factors in small town } \\
\text { construction }\end{array}$ \\
Fan and Xiong & $\begin{array}{l}\text { Indicator system of sustainable town in eastern coastal } \\
\text { region }\end{array}$ \\
Da et al. (2004) & $\begin{array}{l}\text { Indicator system of sustainable development of } \\
\text { little-size town based on the conceptual frame of } \\
\text { pressure-state-response }\end{array}$ \\
Huang and Ye & $\begin{array}{l}\text { Indicator system design of the sustainable development } \\
\text { of the small towns in China }\end{array}$ \\
(2004) & $\begin{array}{l}\text { Application of urban sustainability indicators: A } \\
\text { Shen et al. }\end{array}$ \\
comparison between various practices \\
Guo et al. (2014) & $\begin{array}{l}\text { Comprehensive evaluation analysis of small towns } \\
\text { development level in China's different regions }\end{array}$ \\
Shen and Zhou & $\begin{array}{l}\text { Examining the effectiveness of indicators for guiding } \\
\text { sustainable urbanization in China }\end{array}$ \\
(2014) &
\end{tabular}

established across four dimensions, namely, the scale level, economic development level, social development level, and environmental development level. Table 2 lists the typical literatures referred for enabling indicator system establishment.

In referring to the literatures in Table 2, a list of candidate indicators can be established. The final selection of indicators should comply with certain criteria for ensuring the credibility of indicators (Belnap 1998; Button 2002; Dale and Beyeler 2001; Niemeijer and de Groot 2008; Repetti and Desthieux 2006). Anderson (1991) proposed seven criteria for indicator selection: accessibility, comprehensibility, measurability, salience, availability, comparability, and commonality. According to the principle proposed by the United Nations Statistical Institute for Asia and Pacific (2007), an evaluating indicator should align with the principle of SMART, namely, specific, measurable, achievable, relevant, and time-related. This SMART criterion is adopted in this study to facilitate establish indicators for measuring the development level for a town.

The formation of an evaluating indicator system has also incorporated the advice and opinions from a group of 11 experts who were invited to discuss the validity and efficiency of the indicators. These 11 experts include five professors who have been undertaking research works in the discipline of township development and six town governors from Chongqing. By adopting the SMART indicator selection criteria, referring to the literature in Table 2, and considering experts' views, the process of selecting indictors is as follows:

1. Specific: Those candidate indicators which are ambiguous and general are removed, such as resource damage, proportion of properly planned land use, nutritional status of children, and productivity of unit area of land.

2. Measurable: Those indicators which cannot be quantified are removed, such as soil erosion management, and quality of noise environment.

3. Achievable: Those indicators whose research data are not available in the township statistical systems are removed, such as life expectancy at birth, adult secondary schooling attainment level, average years of education, and proportion of middle-aged people.

4. Relevant: Those indicators which cannot properly reflect the specific characteristics of mountainous areas are removed. For example, some candidate indicators reflect regional characteristics, such as farmland forest network rate, which is mainly adopted for describing plain areas. The indicator proportion of poverty is also removed as the implementation of poverty alleviation policy in China is applicable to the whole country in China. Gender ratio is removed as it is not a social concern of small towns in Southwest China suggested by experts.

5. Time-related: Some indicators are considered outdated and are not significant in current development stage. For example, proportion of immunization against infectious childhood diseases is removed since the implementation of this indicator is strictly compulsory. Following this indicator selection process, a total of 21 indicators were finally selected. It can be found that there are only two indicators in the environmental dimension, namely domestic sewage treatment rate and hazard-free treatment rate for household garbage in township urban area. In line with the advice from experts, these two indicators were added to the dimension of social development. As a result, 21 indicators across three dimensions were established to evaluate the development level of towns in the Southwest region of China, as shown in Table 3.

\section{Data Collection}

The performance data of all the indicators listed in Table 3 were collected from 16 sample towns for the year of 2015, as show in Tables 4-6. These data were collected with the assistant of the 
Table 3. Indicators and their explanation and interpretation

\begin{tabular}{|c|c|c|c|}
\hline Dimensions & Indicators & Explanation & Interpretation \\
\hline \multirow[t]{4}{*}{ Scale level (Sc) } & Total permanent residents & All permanent residents in total area of the township & $\begin{array}{l}\text { Measure the population size in total area } \\
\text { of the township }\end{array}$ \\
\hline & $\begin{array}{l}\text { Township urban permanent } \\
\text { residents }\end{array}$ & All permanent residents in township urban area & $\begin{array}{l}\text { Measure the population size in township } \\
\text { urban area }\end{array}$ \\
\hline & Total area of the township & Administrative area of township government & Measure the size of township area \\
\hline & Township urban area & Built-up area of township government resident & Measure the size of township urban area \\
\hline \multirow{6}{*}{$\begin{array}{l}\text { Economic } \\
\text { development level } \\
\text { (Ec) }\end{array}$} & Per capita GDP & GDP/total permanent residents & $\begin{array}{l}\text { Measure the economic performance and } \\
\text { living standard of township }\end{array}$ \\
\hline & Per capita revenue & Revenue/total permanent residents & $\begin{array}{l}\text { Measure the scope and quantity of public } \\
\text { goods and services provided by } \\
\text { township government }\end{array}$ \\
\hline & Per capita retail sales & Retail sales/total permanent residents & $\begin{array}{l}\text { Measure the realization of resident's } \\
\text { purchasing power of goods and the size } \\
\text { in retail markets }\end{array}$ \\
\hline & $\begin{array}{l}\text { Per capita fixed assets } \\
\text { investment }\end{array}$ & Fixed assets investment/total permanent residents & $\begin{array}{l}\text { Measure the scale, speed, proportional } \\
\text { relations and use direction of fixed assets } \\
\text { investment }\end{array}$ \\
\hline & $\begin{array}{l}\text { Per } 1,000 \text { people number of } \\
\text { tertiary industry enterprises }\end{array}$ & $\begin{array}{l}\text { Number of tertiary industry enterprises/total permanent } \\
\text { residents }\end{array}$ & $\begin{array}{l}\text { Measure the development level of } \\
\text { economic modernization }\end{array}$ \\
\hline & Per 1,000 people number of & Number of secondary industrial enterprises/total & Measure the level of industrialization \\
\hline
\end{tabular}
secondary industrial permanent residents enterprises

Per capita disposable income (Gross family income, income tax, personal social of the township urban residents security expenditure, accounting subsidy)/family population in township urban area, where family population refer to permanent residents in township urban area, and family income includes earnings outside local township area.

Per capita disposable income (Gross family income, income tax, personal social of the township rural residents security expenditure, accounting subsidy)/family permanent population in township rural area, where family permanent population refer to permanent residents in township rural area, and family income includes earnings outside the township area

Social development Medical insurance coverage level (So)

Number of residents enjoyed medical insurance/total permanent residents

Pension coverage

Number of residents enjoyed pension insurance/total permanent residents

Drinkable water penetration rate

Residents using drinkable water/(registered residents + temporary residents)

Gas penetration rate

Residents using gas (including artificial gas, liquefied petroleum gas, natural gas)/(registered residents + temporary residents)

Per capita public leisure and Public leisure and park area/total permanent residents park area

Per 1,000 people the number of secondary school students

Number of secondary school students/total permanent residents

Per capita highway mileage Highway mileage/total permanent residents

Domestic sewage treatment rate

Total domestic sewage volume treated by sewage treatment plant/total discharge of domestic sewage

Hazard-free treatment rate for household garbage in township Hazard-free treatment volume for household garbage/ total amount of household garbage generated

Measure the income level and living standard of township rural residents

Measure the income level and living standard of township urban residents urban area

relevant department officials of the 16 sample towns by referring to their statistical data and yearbooks when the research team conducted practical surveys.

\section{Data Analysis}

This section will analyze the data presented in the previous section by applying the research methods described in the methodology section.

\section{Results From Applying PCA Method}

The significant test for applying PCA in our research has been conducted by the measurements of the Kaiser-Meyer-Olkin (KMO) of Sampling Adequacy test and Bartlett's test of Sphericity (Bartlett 1950; Kaiser 1960). According to Table 3, the indicators selected in this study are classified in three dimensions, for which the PCA method was conducted within each of the three dimensional indicators. By applying the data in Tables 4-6, the calculation process for these two measurements was conducted by using the 
software SPSS 22.0. The results show that KMO values of the three dimensions were $0.672,0.638$, and 0.508 respectively. These three values meet the requirements of PCA since they are all larger than 0.5. In addition, the results of the Bartlett's test of Sphericity in three dimensions indicate that PCA is effective with these data. Because the values of significant level in three dimensions are $0.002,0,0$, respectively, which are all less than 0.05 , the significance test results support that PCA is suitable in this study.

The selection of principal components is usually based on the principle that the total proportion of the cumulative variance is more than $85 \%$. According to this principle, by applying the data in Tables 4-6, the outcomes of PCA for all three indicator dimensions were obtained (with the assistance of software SPSS 22.0), as shown in Table 7.

These analysis results suggest that there are 10 principle components across three dimensions. According to the principle of PCA, these 10 principle components do not have their own practical meaning in reality but can represent the information of the 21

Table 4. Research data of 16 sample towns from the dimension of scale level

\begin{tabular}{lcccc}
\hline Town & $\begin{array}{c}\text { Total } \\
\text { permanent } \\
\text { residents } \\
\text { (person) }\end{array}$ & $\begin{array}{c}\text { Township urban } \\
\text { permanent } \\
\text { residents } \\
\text { (person) }\end{array}$ & $\begin{array}{c}\text { Total area } \\
\text { of the } \\
\text { township } \\
\left(\mathrm{km}^{2}\right)\end{array}$ & $\begin{array}{c}\text { Township } \\
\text { urban area } \\
\left(\mathrm{km}^{2}\right)\end{array}$ \\
\hline Chaole & 12,901 & 2,940 & 100.8 & 0.4 \\
Dalucao & 11,800 & 1,200 & 96 & 0.8 \\
Degan & 79,532 & 32,500 & 122 & 4 \\
Dingzhai & 22,749 & 3,456 & 193 & 15.2 \\
Fangshan & 28,204 & 915 & 52.75 & 2 \\
Fenshuiling & 36,961 & 7,600 & 69 & 0.42 \\
Gaoleshan & 73,580 & 71,350 & 322 & 12 \\
Heishan & 7,541 & 4,200 & 98.3 & 1.2 \\
Lushi & 21,000 & 4,000 & 25.6 & 1.5 \\
Qiantang & 92,888 & 23,000 & 134.15 & 2.26 \\
Tanghe & 13,759 & 3,756 & 61 & 1.5 \\
Tangya & 30,330 & 3,624 & 338 & 1.5 \\
Tiaodeng & 14,400 & 10,666 & 49.48 & 2.5 \\
Yanwo & 33,269 & 8,733 & 71.19 & 2.57 \\
Yongxing & 38,283 & 18,498 & 168.5 & 8.15 \\
Zhongliangshan & 18,997 & 8,281 & 40.47 & 0.33 \\
\hline
\end{tabular}

original indicators. Specifically, P1, P2, and P3 can represent the information of the four indicators in the dimension of scale level. P4, P5, and P6 can represent the information of eight indicators in the dimension of economic development level. P7, P8, P9, and P10 can represent the information of nine indicators in the dimension of social development. The data in Tables 4-6 can therefore be converted into a new set of data described by the 10 principal components. The process of converting the data is conducted by the assistance of software SPSS 22.0, and the new set of data is presented in Table 8.

\section{Results From TOPSIS Analysis}

By applying the data presented in Tables 7 and 8 to Eqs. (1)-(4), the results of the closeness coefficients for each of the three indicator dimensions were obtained, designated respectively as $C_{i}^{D_{s}}$ (scale level dimension), $C_{i}^{D_{E}}$ (economic development dimension), $C_{i}^{D_{D}}$ (social development level dimension), as shown in Table 9. By using these closeness coefficients, the rankings under each of the three dimensions between the 16 sample towns were generated, as described in Table 9. The analysis results in Table 9 can also be depicted graphically in Figs. 2-4, respectively.

\section{Analysis Results on Unbalanced Degree}

According to the research method defined, the variable coefficient was used to indicate the unbalanced development degree between towns. By using the data in Table 9 to the Eq. (5), the values of variable coefficient under three dimensions were calculated, as presented in Table 10.

It can be seen from Table 10 that the unbalanced development in the dimensions of both scale level and economic level between the 16 sample towns are very significant, evidenced by the value of variable coefficients of 0.834 and 0.813 respectively. The data in Fig. 2 support this by showing that there are three groups of town scales, where Gaoleshan is the largest towns. Degan, Dingzhai, Qiantang, Yongxing, and Tangya are medium-sized, whilst the others are of a small scale. Fig. 3 shows that the gap between towns is very significant in terms of economic development level. In

Table 5. Research data of 16 sample towns from dimension of the economic development level

\begin{tabular}{|c|c|c|c|c|c|c|c|c|}
\hline Town & $\begin{array}{c}\text { Per capita } \\
\text { GDP } \\
(10,000 \\
\text { RMB/ } \\
\text { person })\end{array}$ & $\begin{array}{c}\text { Per capita } \\
\text { revenue } \\
(10,000 \\
\text { RMB/ } \\
\text { person) }\end{array}$ & $\begin{array}{l}\text { Per capita } \\
\text { retail sales } \\
(10,000 \\
\text { RMB/ } \\
\text { person })\end{array}$ & $\begin{array}{l}\text { Per capita fixed } \\
\text { assets } \\
\text { investment } \\
(10,000 \mathrm{RMB} / \\
\text { person })\end{array}$ & $\begin{array}{c}\text { Per } 1,000 \text { people } \\
\text { number of } \\
\text { tertiary industry } \\
\text { enterprises (Unit/ } \\
1,000 \text { persons) }\end{array}$ & $\begin{array}{c}\text { Per } 1,000 \text { people } \\
\text { number of } \\
\text { secondary } \\
\text { industrial } \\
\text { enterprises (Unit/ } \\
1,000 \text { persons) }\end{array}$ & $\begin{array}{l}\text { Per capita } \\
\text { disposable } \\
\text { income of the } \\
\text { township urban } \\
\text { residents (RMB/ } \\
\text { person) }\end{array}$ & $\begin{array}{c}\text { Per capita } \\
\text { disposable } \\
\text { income of the } \\
\text { township rural } \\
\text { residents (RMB/ } \\
\text { person) }\end{array}$ \\
\hline Chaole & 2.1704 & 0.0848 & 0.9302 & 1.6278 & 17.9056 & 1.6278 & 13,012 & 10,142 \\
\hline Dalucao & 1.0776 & 0.0047 & 0.1538 & 2.5424 & 0.4237 & 0 & 15,001 & 8,506 \\
\hline Degan & 13.2396 & 0.7795 & 2.0976 & 18.5263 & 39.6318 & 5.5198 & 28,181 & 15,535 \\
\hline Dingzhai & 1.1246 & 0.0879 & 0.5275 & 2.1997 & 8.7916 & 2.1979 & 7,500 & 6,500 \\
\hline Fangshan & 2.5584 & 0.0473 & 0.8165 & 1.5601 & 1.7728 & 0.4255 & 15,890 & 13,656 \\
\hline Fenshuiling & 0.5952 & 0.0176 & 0.4206 & 1.3636 & 2.7056 & 0.0812 & 12,996 & 11,925 \\
\hline Gaoleshan & 2.9397 & 0.0667 & 2.1209 & 0.53 & 107.896 & 1.0873 & 21,000 & 7,962 \\
\hline Heishan & 7.1684 & 0.1107 & 0.9272 & 0.1233 & 44.026 & 1.4587 & 18,901 & 10,789 \\
\hline Lushi & 1.4762 & 0.4048 & 0.8571 & 4.1667 & 6.0952 & 0.1429 & 21,500 & 15,600 \\
\hline Qiantang & 1.5455 & 0.03 & 0.7611 & 0.8397 & 18.7538 & 0.829 & 29,720 & 13,336 \\
\hline Tanghe & 1.8606 & 0.1087 & 0.2402 & 0.5678 & 35.2497 & 0.7995 & 24,738 & 12,654 \\
\hline Tangya & 1.5595 & 0.1157 & 0.1999 & 0.8309 & 52.2585 & 0.1978 & 10,021 & 6,664 \\
\hline Tiaodeng & 34.5417 & 0.2083 & 3.4722 & 6.7361 & 111.111 & 14.5833 & 30,320 & 18,200 \\
\hline Yanwo & 1.575 & 0.0092 & 0.9318 & 0.6312 & 19.147 & 0.511 & 24,643 & 11,666 \\
\hline Yongxing & 2.4032 & 0.0251 & 0.8881 & 1.9361 & 3.5264 & 4.7018 & 25,531 & 10,151 \\
\hline Zhongliangshan & 4.4143 & 0.0505 & 0.8482 & 0.7808 & 63.1679 & 10.528 & 21,000 & 14,596 \\
\hline
\end{tabular}


Table 6. Research data of 16 sample towns from the dimension of social development level

\begin{tabular}{|c|c|c|c|c|c|c|c|c|c|}
\hline Town & $\begin{array}{c}\text { Medical } \\
\text { insurance } \\
\text { coverage } \\
(\%)\end{array}$ & $\begin{array}{c}\text { Pension } \\
\text { coverage } \\
(\%)\end{array}$ & $\begin{array}{l}\text { Drinkable } \\
\text { water } \\
\text { penetration } \\
\text { rate }(\%)\end{array}$ & $\begin{array}{c}\text { Gas } \\
\text { penetration } \\
\text { rate }(\%)\end{array}$ & $\begin{array}{c}\text { Per capita } \\
\text { public } \\
\text { leisure and } \\
\text { park area } \\
\left(\mathrm{m}^{2} / \text { person }\right)\end{array}$ & $\begin{array}{l}\text { Per } 1,000 \\
\text { people the } \\
\text { number of } \\
\text { secondary } \\
\text { school } \\
\text { students } \\
\text { (person) }\end{array}$ & $\begin{array}{c}\text { Per capita } \\
\text { highway } \\
\text { mileage } \\
\text { (km/person) }\end{array}$ & $\begin{array}{l}\text { Domestic } \\
\text { sewage } \\
\text { treatment } \\
\text { rate }(\%)\end{array}$ & $\begin{array}{l}\text { Hazard-free } \\
\text { treatment rate } \\
\text { for household } \\
\text { garbage in } \\
\text { township urban } \\
\text { area }(\%)\end{array}$ \\
\hline Chaole & 98.9 & 92.3 & 92.3 & 28 & 3.7206 & 36.5863 & 0.014 & 67 & 93.1 \\
\hline Dalucao & 92.6 & 85.3 & 51 & 0 & 0.0932 & 0 & 0.06 & 2.5 & 5.5 \\
\hline Degan & 100 & 95 & 100 & 68 & 151.763 & 84.9469 & 0.034 & 80 & 100 \\
\hline Dingzhai & 87.6 & 96 & 90 & 30 & 0.02198 & 13.627 & 0.01 & 30 & 50 \\
\hline Fangshan & 95 & 100 & 80 & 85.6 & 0.0709 & 14.1115 & 0.0012 & 60 & 80 \\
\hline Fenshuiling & 98 & 90 & 100 & 66 & 0.3057 & 28.8683 & 0.0021 & 70 & 100 \\
\hline Gaoleshan & 100 & 100 & 90 & 30 & 193.217 & 164.814 & 0.005 & 60 & 80 \\
\hline Heishan & 95 & 90 & 80 & 60 & 1.979 & 9.5478 & 0.0064 & 70 & 100 \\
\hline Lushi & 100 & 100 & 88 & 80 & 0.381 & 18.1905 & 0.02 & 85 & 90 \\
\hline Qiantang & 98 & 95 & 62.5 & 40 & 0.2153 & 26.9141 & 0.0019 & 90 & 100 \\
\hline Tanghe & 100 & 95 & 85 & 22 & 0.596 & 26.7461 & 0.005 & 80 & 100 \\
\hline Tangya & 99 & 100 & 90 & 0 & 0.033 & 33.9268 & 0.0053 & 77 & 95 \\
\hline Tiaodeng & 100 & 90 & 100 & 30 & 0.2083 & 83.3333 & 0.0038 & 70 & 100 \\
\hline Yanwo & 95 & 86 & 90 & 20 & 0.0601 & 36.0696 & 0.0037 & 65 & 85 \\
\hline Yongxing & 96 & 99 & 90 & 30 & 1.2221 & 38.6333 & 0.0033 & 62 & 100 \\
\hline Zhongliangshan & 97.2 & 98 & 95 & 10 & 0.0611 & 28.3203 & 0.006 & 70 & 90 \\
\hline
\end{tabular}

Table 7. Cumulative variances and weighting values of principal components

\begin{tabular}{lcccc}
\hline & & & & $\begin{array}{c}\text { The } \\
\text { weighting } \\
\text { values of } \\
\text { principal }\end{array}$ \\
$\begin{array}{l}\text { Indicator } \\
\text { dimensions }\end{array}$ & $\begin{array}{c}\text { Principal } \\
\text { components }\end{array}$ & $\begin{array}{c}\text { Variances } \\
(\%)\end{array}$ & $\begin{array}{c}\text { Cumulative } \\
\text { variances } \\
(\%)\end{array}$ & $\begin{array}{c}\text { components } \\
(\%)\left(W_{P}\right)\end{array}$ \\
\hline Scale level & P1 & 63.127 & 63.127 & 66.823 \\
& P2 & 20.432 & 83.559 & 21.628 \\
Economic & P3 & 10.910 & 94.469 & 11.549 \\
development & P4 & 57.188 & 57.188 & 65.776 \\
level & P5 & 18.859 & 76.048 & 21.691 \\
Social & P6 & 10.896 & 86.944 & 12.532 \\
development & P7 & 43.694 & 43.694 & 51.333 \\
level & P8 & 20.558 & 64.252 & 24.152 \\
& P9 & 10.883 & 75.134 & 12.786 \\
\hline & P10 & 9.984 & 85.118 & 11.730 \\
\hline
\end{tabular}

particular, Tiaodeng and Degan enjoy a much higher economic development level than other towns. Nevertheless, it appears that the social development is not significantly different between the 16 sample towns, indicated by a smaller variable coefficient of 0.266 . There is a special case of Dalucao, as shown in Fig. 4, the social development level of which is much lower than the other towns. The onsite visit to this town showed that there is a very low standard of infrastructure construction, evidenced by, for example, an absence of gas supply and education institutes even at middle-school level.

\section{Reasons Contributing to the Unbalanced Development Phenomenon}

In this section, the reasons contributing to the unbalanced development phenomenon among the towns in Southwest China will be discussed. These discussions are supported by the practical visits to the 16 sample towns and the in-depth semistructured interviews

Table 8. Principal component scores $\left(F_{P i}\right)$

\begin{tabular}{|c|c|c|c|c|c|c|c|c|c|c|}
\hline Town & $\mathrm{P} 1$ & $\mathrm{P} 2$ & P3 & P4 & P5 & P6 & P7 & P8 & P9 & P10 \\
\hline Chaole & -1.1269 & 0.1538 & -0.4503 & -1.0637 & -0.0189 & 0.5038 & 0.3752 & -0.2681 & -0.6406 & 0.5366 \\
\hline Dalucao & -1.1853 & 0.2422 & -0.3748 & -1.9142 & 0.3096 & 0.21 & -5.7995 & 1.2168 & 0.0147 & 0.9906 \\
\hline Degan & 1.5277 & -1.375 & 0.4487 & 4.0644 & 3.2495 & 0.9949 & 1.339 & 2.5358 & 1.1489 & 1.0253 \\
\hline Dingzhai & 1.1043 & 2.2971 & 0.9174 & -1.9294 & 0.0616 & 1.4264 & -2.4278 & -0.3606 & 0.3479 & -2.331 \\
\hline Fangshan & -0.9899 & -0.1772 & 0.2247 & -0.8984 & 0.3417 & -0.5606 & -0.6764 & -0.5668 & 1.9742 & -0.8058 \\
\hline Fenshuiling & -0.6974 & -0.6422 & -0.0322 & -1.5849 & 0.2776 & -0.1815 & 0.4675 & -0.6299 & 0.134 & 0.4845 \\
\hline Gaoleshan & 4.5184 & 0.0713 & 0.2322 & 0.2934 & -1.6937 & 1.2641 & 2.0929 & 3.6953 & -0.0907 & -0.9726 \\
\hline Heishan & -1.1169 & 0.3598 & -0.3313 & -0.3421 & -0.5157 & 0.1675 & -0.7584 & -0.8641 & 0.5427 & 0.4673 \\
\hline Lushi & -1.2225 & -0.2383 & 0.372 & 0.2463 & 1.773 & -0.6375 & 0.4765 & -0.2614 & 1.7112 & 0.6911 \\
\hline Qiantang & 1.3615 & -1.7235 & 0.0834 & -0.2592 & 0.0228 & -1.59 & 0.3258 & -1.009 & 0.2206 & 0.7468 \\
\hline Tanghe & -1.1793 & 0.0949 & 0.0438 & -0.5737 & 0.0529 & -0.9059 & 0.9999 & -0.8194 & -0.7021 & 0.499 \\
\hline Tangya & 0.5797 & 0.8961 & -2.1667 & -1.8087 & -0.392 & 1.5156 & 1.323 & -0.7556 & -1.0865 & -0.4886 \\
\hline Tiaodeng & -0.9072 & 0.0498 & 0.3426 & 5.9079 & -1.9639 & 0.0358 & 1.279 & 0.0806 & -1.2718 & 0.4946 \\
\hline Yanwo & -0.4945 & -0.2726 & 0.2444 & -0.6574 & -0.1753 & -0.8868 & -0.3877 & -0.6755 & -1.263 & 0.251 \\
\hline Yongxing & 0.9987 & 0.6171 & 0.3332 & -0.3915 & -0.1189 & -0.7689 & 0.5831 & -0.59 & -0.1774 & -0.9165 \\
\hline Zhongliangshan & -1.1703 & -0.3534 & 0.1129 & 0.9111 & -1.2102 & -0.5869 & 0.7877 & -0.7283 & -0.8621 & -0.6723 \\
\hline
\end{tabular}


Table 9. Results from TOPSIS analysis

\begin{tabular}{lcrrrrr}
\hline Town & $C_{i}^{D_{s}}$ & Ranking & $C_{i}^{D_{E}}$ & Ranking & $C_{i}^{D_{D}}$ & Ranking \\
\hline Chaole & 0.107 & 14 & 0.140 & 12 & 0.704 & 10 \\
Dalucao & 0.110 & 12 & 0.095 & 15 & 0.143 & 16 \\
Degan & 0.464 & 2 & 0.772 & 2 & 0.886 & 2 \\
Dingzhai & 0.443 & 3 & 0.100 & 14 & 0.406 & 15 \\
Fangshan & 0.110 & 11 & 0.158 & 11 & 0.602 & 13 \\
Fenshuiling & 0.121 & 9 & 0.102 & 13 & 0.705 & 9 \\
Gaoleshan & 0.888 & 1 & 0.281 & 5 & 0.923 & 1 \\
Heishan & 0.117 & 10 & 0.210 & 7 & 0.587 & 14 \\
Lushi & 0.101 & 15 & 0.306 & 4 & 0.721 & 6 \\
Qiantang & 0.433 & 4 & 0.222 & 6 & 0.683 & 11 \\
Tanghe & 0.109 & 13 & 0.187 & 9 & 0.733 & 5 \\
Tangya & 0.332 & 6 & 0.092 & 16 & 0.750 & 4 \\
Tiaodeng & 0.125 & 8 & 0.818 & 1 & 0.776 & 3 \\
Yanwo & 0.159 & 7 & 0.174 & 10 & 0.621 & 12 \\
Yongxing & 0.401 & 5 & 0.206 & 8 & 0.710 & 8 \\
Zhongliangshan & 0.094 & 16 & 0.354 & 3 & 0.719 & 7 \\
\hline
\end{tabular}



Fig. 2. Ranking results of 16 sample towns from the dimension of scale level.



Fig. 3. Ranking results of 16 sample towns from the dimension of economic development level.



Fig. 4. Ranking results of 16 sample towns from the dimension of social development level.
Table 10. Degree of unbalanced development in three dimensions between 16 sample towns

\begin{tabular}{lc}
\hline Dimensions & Variable coefficients \\
\hline Scale level & 0.834 \\
Economic development level & 0.813 \\
Social development level & 0.266 \\
\hline
\end{tabular}

with the officials working in these sample towns. Two field survey photos are provided in Figs. 5 and 6 which portray the typical appearance of small towns in Southwest China.

\section{The Reasons Contributing to Unbalanced Development in Township Scale}

The reasons contributing to significant unbalanced scale level can be summarized as follows.

First, different geographical conditions create a variation in the size of towns. Historically, housing clusters were often distributed around a pond or a river and these housing clusters gradually become towns (Tan and Li 2013). However, in mountainous regions, as referenced in this study, towns are usually situated at the foot of hills or mountains and beside rivers or streams. According to the practical surveys and in-depth interviews, it was found that some towns cannot expand their town areas because the surrounding mountains restricts the area into which they can expand. Other towns are located at the foot of hills or mountains but next to other towns or cities. They can be in larger size because they can merge with other towns around them and also absorb the population from the other towns in the process of urbanization. This is why some towns in Southwest China are becoming larger but other towns remain unchanged in size, and explains why the degree of unbalance in terms of scale level between towns is significant.

Second, there are no strict criteria for defining the size of a town in China, although there are guidelines for the establishment of town, as stipulated in the designated town standards (the State Council of China 1984). As a result, many small towns have emerged even though they have a small geographical area and do not have enough population to support town development, as reported by interviewees in the sample townships. This reason has exacerbated the unbalanced degree in scale level between towns. Hence, it is considered important to have specific scale standards for the establishment of a town, such as population density, geographical area, and infrastructure conditions.

The significant unbalanced development between towns in scale level indicates that the less developed towns in Southwest China are mainly limited by their small size. Interviewees suggest that towns in Southwest China are too numerous but small in size. They should change the development pattern by pursuing the development quality instead of quantity through town-integration to receive an agglomeration effect. By this means they can ensure the space and resource supply for town development and reduce administrative costs as well. In addition, the government should consider special favorable measures to support the development of characteristic or advantageous industries to attract migrations in order to increase township size, as pointed out by interviewees.

\section{The Reasons Contributing to Unbalanced Development in Economic Development}

The significant unbalanced phenomenon in economic development level is mainly caused by the following three reasons.

First, there are different self-borne conditions between towns, such as physical conditions, the existing economic fundamentals, 


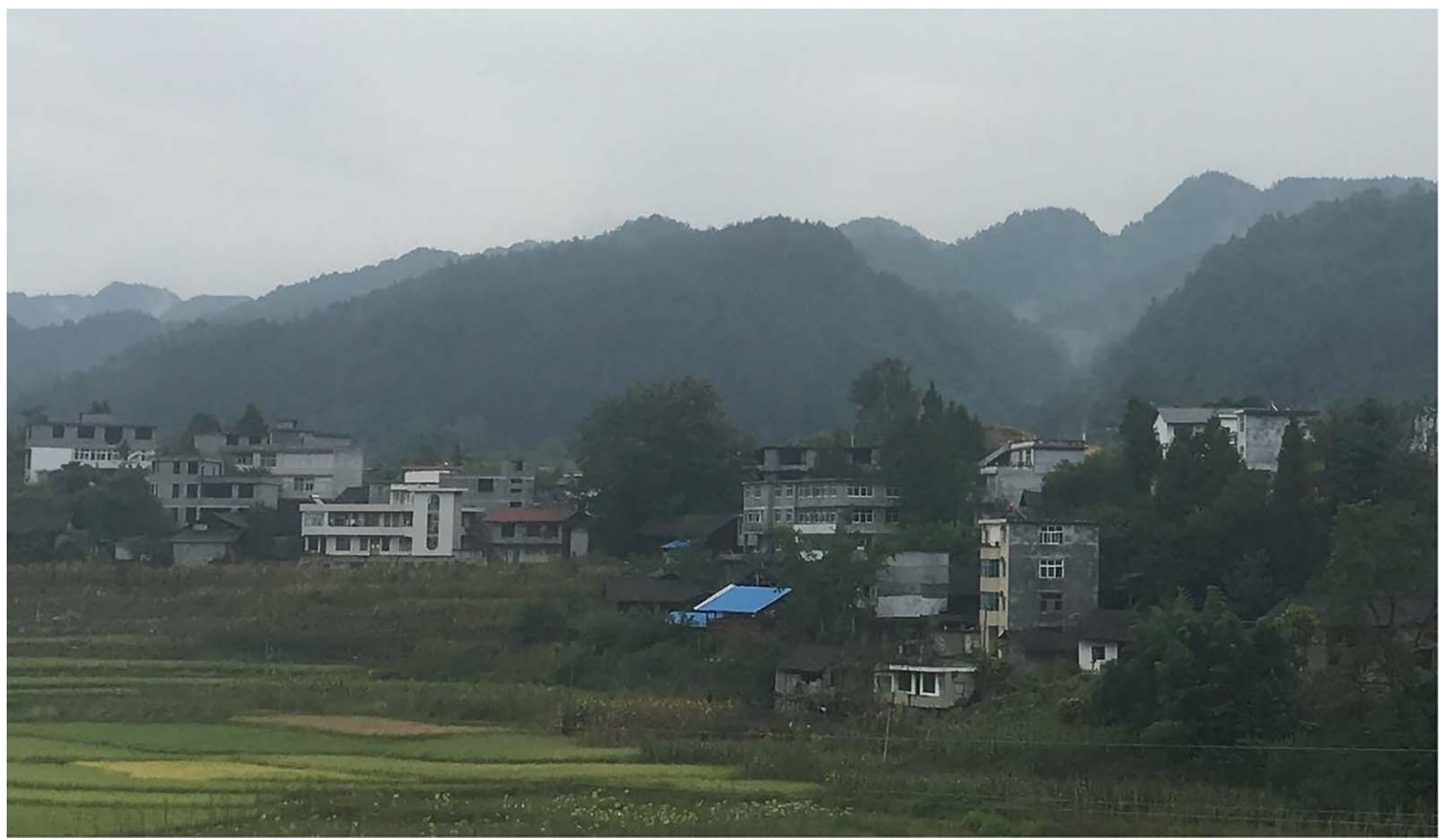

Fig. 5. Field survey in Dingzhai township. (Image by Ning Xiong.)

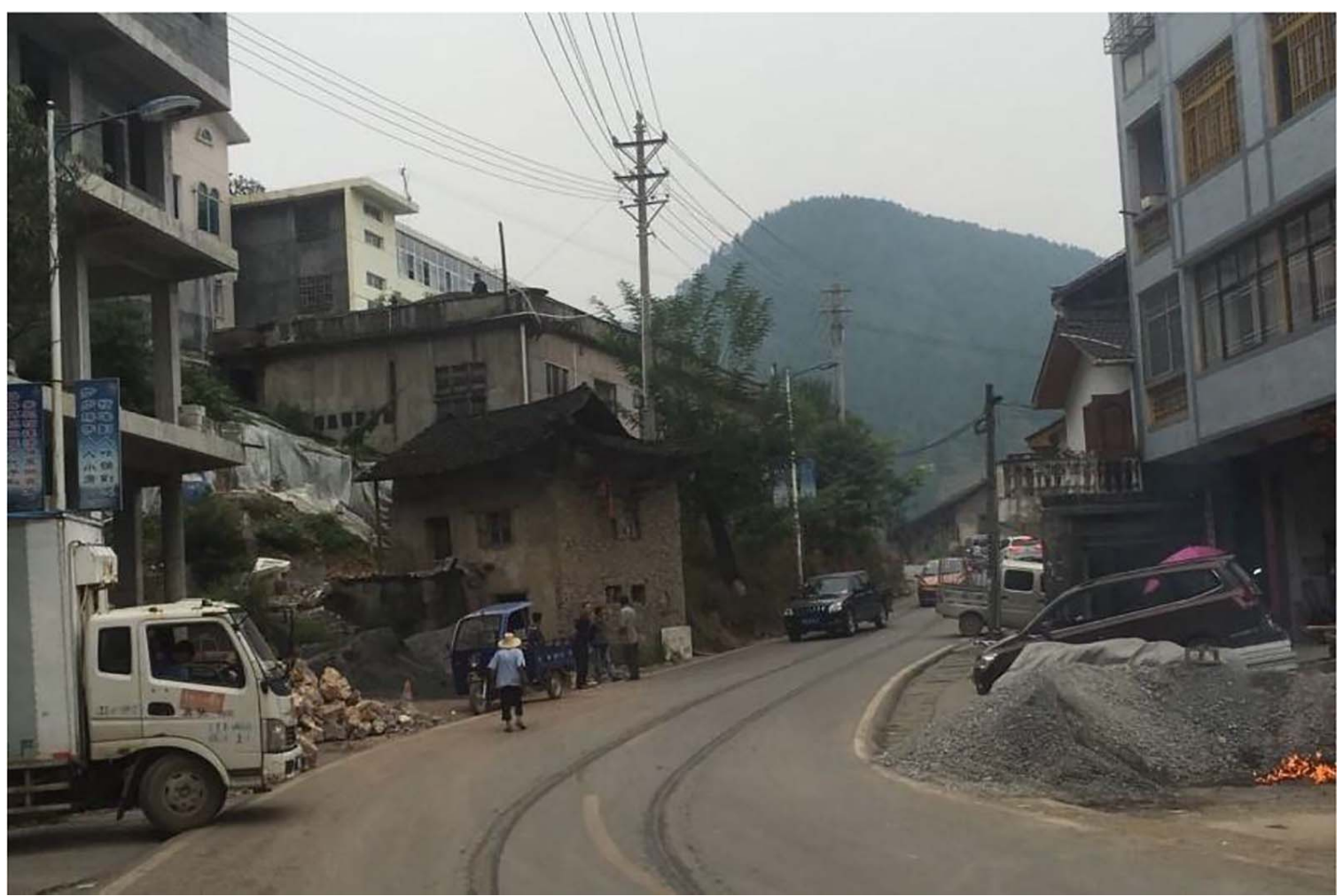

Fig. 6. Field survey in Tangya township. (Image by Ning Xiong.)

natural resources, location conditions, historical and cultural backgrounds, and others. Towns with different mixtures of self-borne conditions have been adopting diverse strategies to foster their local economic development. It was found during the practical surveys and interviews that towns with better economic development have unique resources and tend to utilize such resources more effectively. For example, Tiaodeng, Zhongliang, Degan, and Gaoleshan are economically more advanced, and enjoy the location advantage of being next to big cities or urban areas. Heishan has a wealth of tourism resources, with the 5A-class tourist attraction of the Black Valley Scenic Area. Lushi has developed a national agricultural science and technology demonstration park. Yongxing is a historic town with rich culture and a well-developed agricultural and commercial base. In fact, Yongxing is certified as one of the historical and cultural towns in Guizhou province. 
Discussions during the in-depth interviews further suggested that all those economically better towns have developed secondary or tertiary industries by utilizing their self-borne resources, or have developed advanced agriculture bases. However, those less developed towns mainly engage in small-scale traditional agriculture activities due to the restrictions of graphical conditions, such as Tangya, Dalucao, Dingzhai, Fenshuiling, Chaole, and Fangshan. The agriculture activities in these less developed towns cannot generate much economic benefits, and as a result, many local people choose to leave for work in other places. This phenomenon of leaving hometowns for other places to make a living is defined as wage economy. Under this circumstance, the unbalanced degree of economic development between towns is increasing.

Second, the designation for a number of key towns or demonstration towns by government contributes to the increase of unbalanced economic development between towns as these designated towns are given with more favorable policies and investment resources to support their economic development. For example, these key towns are allowed to develop industrial parks or agricultural demonstration parks, and thus they can generate more economic benefits. Industrial parks are a kind of development mode, with sufficient resource investment by the government (Geng and Zhao 2009). For example, Degan established the Degan industrial park in 2002, which focuses on equipment manufacturing and grain and oil processing. The establishment of this industrial park has been strongly supported by its upper level government, namely, Jiangjin District of Chongqing Government. By the end of 2015, the industrial park had attracted 98 industrial enterprises, of which 11 are the branch factories of the world's top 500 enterprises. It was reported during the interview discussion that the proportion of GDP contribution by these enterprises in the industrial park to Degan town was more than $80 \%$ in 2015 . Thus Degan has been in a much more advanced position economically, which in turn has improved its ability to pay for improvements to infrastructure, living standards, and public services in the town.

Third, these economically stronger towns will continue to be better, as explained by the cumulative causation effect (Myrdal 1957). The discussions in the interview process reveal that towns with good economic conditions have stronger financial ability to catch up with development opportunities, and thus can maintain a competitive advantage in the market. However, those economically weak towns have fewer financial resources to develop industries. This is further contributed to by the increasingly stringent environmental policy imposed by government. These economically weak towns often have better natural environment but are not allowed to develop industry at the expense of environmental damage. In this context, this cumulative causation has further exacerbated the disadvantage of those economically weak towns. This aspect also helps to understand why the unbalanced phenomenon in the dimension of economic development level between towns is significant.

These three reasons contributing to unbalanced development in the dimension of economic development indicate that economically weak towns generally do not utilize their resources effectively to develop industry but rather overwhelmingly engage in traditional agriculture activities. The government should introduce tailor measures to help these less developed towns effectively utilize their resources to develop secondary and tertiary industries. For example, these small town governments should form their own development plans which are tailor-made and targeted to utilize their self-borne resources, and higher-level government should provide financial and policy support to help the township implement the plan.

\section{The Reason Contributing to Unbalanced Development in Social Development}

According to the analysis results in the previous section, social development is reasonably balanced between the sample towns. This is considered due to the enforcement of policy implementation to support the social development for all towns, particularly in Southwest China. This was reported during the discussions with interviewees, pointing out that the government has been increasing investments in public services and infrastructures especially to those towns in mountainous areas in West China. As a result, significant improvements of infrastructure and social security systems have been achieved in the majority of towns, thus the gap between these towns in the dimension of social development is not that significant compared with the dimensions of economic development and scale level.

To summarize from the above discussions, the unbalanced development between towns in the context of the southwest mountainous region in China is more significant in both scale and economic standard than that in the dimensions of social development. This may indicate that the improvement of social development has been given priority across all towns by government. Nevertheless, it is considered that the development of advanced industry to improve the township local economy should be given priority, particularly in those economically less developed towns, as raised by the interviewees. In fact, the interviewees further pointed out that developing advanced industry is a major approach for driving the sustainable development of these economically less developed towns, given the fact that economic development can not only improve living conditions of township residents, but also help these towns generate more fiscal revenue for environment governance and other aspects of sustainable development. The interview discussions demonstrate that economically weak towns can consider, for example, the development of tourism, whilst the economically better towns can continue their focus of engaging secondary and tertiary industries. Tourist industry is defined as a labor-intensive industry, which can create a huge number of employment opportunities for local residents and simultaneously promote the development of related industries, thus promoting economic development holistically (Blake et al. 2008; Spenceley and Meyer 2012). In addition, developing tourism is conductive to avoiding the damage or loss of the unique rural identity and landscape.

It was further found during the in-depth interviews that the development performance of towns is highly related to the education background and work experience of the local officials. In particular, the quality of those township officials whose jobs request professional knowledge has a direct effect on the development performance of the concerned towns. Difference in the quality of officials is considered an important contributor to the unbalanced phenomenon between towns. It appears that those better-developed towns tend to have government officials with a higher education background in professional knowledge and a richer experience in the practice of township management. Therefore, it is highly recommended that township government consider seeking advice from expert consultants to mitigate the negative effects of the shortage of professional officials, or recruit talents and professionals to work as government officials in these towns by offering more incentive measures.

\section{Conclusions}

There is a significant degree of unbalanced development between townships in Southwest China both in scale and in economic 
performance, whilst the performance of social development is reasonably balanced between towns. The main reasons contributing to the unbalanced development scale include the difference in geographical environment between towns, historical events, and shortage of standards for town planning. The major reasons contributing to the unbalanced economic development between towns include the difference in self-borne resource conditions, different policy measures imposed by government, and the consequence of cumulative causation. The main reason for the relatively balanced social development between towns is that the government increased investments in infrastructure and social security delivery for all towns across the whole country. The discussions revealed that the improvement of balanced social development does not necessarily generate better economic benefits equally to all towns. It is worth mentioning that the quality of governance is one of the major reasons affecting the overall development performance between towns.

The findings in this study provide a good understanding of the phenomenon regarding the unbalanced development between different towns in Southwest China, which is identified as a lack of knowledge in existing research works. They present valuable information and reference to relevant government departments for promoting balanced development between towns by adopting proper policy measures. The government should implement tailor-made policies for different towns by considering the background and characteristics of individual towns. This could enable the effectiveness of policy implementation and therefore mitigate the phenomenon of unbalanced development between towns. For example, favorable tax policies could be adopted in those less developed towns, and special financing channels could be established for those less developed towns to help develop, for example, a tourist industry by utilizing their unique local resources. On the other hand, the better-developed towns should be supported to maintain their focus on their advantageous industries, and should also be encouraged to develop industries jointly with those towns that are lagging behind. In addition, townships should consider adjusting development orientation or patterns by pursuing development quality instead of quantity through town-integration to achieve an agglomeration effect.

This paper presents a theoretical framework by examining the unbalanced development phenomenon between towns during the rapid urbanization process in China. It contributes to developing the literature in the research domain of urban-rural studies. The study can be extended to future research works to examine the effectiveness of strategies adopted by various towns, thus best practices can be identified and formulated as experiences and references for better sharing. It is further recommended to extend this study to establish benchmarks for measuring the unbalanced development degree between towns in referring to the various development stages in different countries globally.

\section{Data Availability Statement}

All data, models, or code were generated or used during the study appear in the published article.

\section{Acknowledgments}

This work was supported by the National Social Science Foundation of China (Grant Nos. 15BJY038 and 17ZDA062) and a research grant from the Hong Kong Polytechnic University (PolyU 152108/17E).

\section{References}

Anderson, V. 1991. “Alternative economic indicators.” Ecol. Econ. 7 (3): 255-256.

Barbier, E. B. 1987. "The concept of sustainable economic development." Environ. Conserv. 14 (2): 101-110. https://doi.org/10.1017 /S0376892900011449.

Barro, R. J., and X. Sala-I-Martin. 1992. “Convergence.” J. Polit. Econ. 100 (2): 223-251. https://doi.org/10.1086/261816.

Bartlett, M. S. 1950. "Tests of significance in factor analysis." Br. J. Stat. Psychol. 3 (2): 77-85. https://doi.org/10.1111/j.2044-8317.1950 .tb00285.x.

Bellandi, M., and M. R. Di Tommaso. 2005. "The case of specialized towns in Guangdong, China.” Eur. Plann. Stud. 13 (5): 707-729. https://doi .org/10.1080/09654310500139244.

Belnap, J. 1998. "Environmental auditing: Choosing indicators of natural resource condition: A case study in Arches National Park, Utah, USA." Environ. Manage. 22 (4): 635-642. https://doi.org/10.1007 /s002679900135.

Blake, A., J. S. Arbache, M. T. Sinclair, and V. Teles. 2008. "Tourism and poverty relief." Ann. Tourism Res. 35 (1): 107-126. https://doi.org/10 .1016/j.annals.2007.06.013.

Bossel, H. 1999. Indicators for sustainable development: Theory, method, applications. Winnipeg, Canada: International Institute for Sustainable Development.

Broadberry, S., and B. Gupta. 2006. "The early modern great divergence: Wages, prices and economic development in Europe and Asia, 1500 1800." Econ. Hist. Rev. 59 (1): 2-31. https://doi.org/10.1111/j.1468 $-0289.2005 .00331 . x$

Brown, L. R. 1987. State of the world 1987: A worldwatch institute report on progress toward a sustainable society. Richmond, TX: WW Norton \& Company.

Button, K. 2002. "City management and urban environmental indicators." Ecol. Econ. 40 (2): 217-233. https://doi.org/10.1016/S0921-8009(01) 00255-5.

Cao, S. X., Y. Lv, H. R. Zheng, and X. Wang. 2014. "Challenges facing China's unbalanced urbanization strategy." Land Use Policy 39: 412 415. https://doi.org/10.1016/j.landusepol.2013.12.004.

Da, K. N., Y. L. Zhao, X. H. Li, and X. Y. Qin. 2004. "Index system of sustainable development of little-size town based on the conceptual frame of pressure-state-response." [In Chinese.] Ecol. Econ 20 (12): 38-40. https:// doi.org/10.3969/j.issn.1671-4407.2004.12.009.

Dale, V. H., and S. C. Beyeler. 2001. "Challenges in the development and use of ecological indicators." Ecol. Indic. 1 (1): 3-10. https://doi.org/10 .1016/S1470-160X(01)00003-6.

Dyer, J. S. 1990. "Remarks on the analytic hierarchy process." Manage. Sci. 36 (3): 249-258. https://doi.org/10.1287/mnsc.36.3.249.

Ertuğrul, İ, and N. Karakaşoğlu. 2009. "Performance evaluation of Turkish cement firms with fuzzy analytic hierarchy process and TOPSIS methods." Expert. Syst. Appl. 36 (1): 702-715. https://doi .org/10.1016/j.eswa.2007.10.014.

Fan, W. G., and N. Xiong. 2002. "The indicator system of sustainable town in eastern coastal region.” [In Chinese.] Econ. Geogr. 22 (1): 37-40,62. https://doi.org/10.3969/j.issn.1000-8462.2002.01.009.

Forman, R. T. T. 1990. "Ecologically sustainable landscapes: The role of spatial configuration." In Changing landscapes: An ecological perspective, edited by I. S. Zonneveld and R. T. T. Forman, 261-278. New York: Springer.

Friedmann, J. 1986. "World city hypothesis." Dev. Change 17 (1): 69-83. https://doi.org/10.1111/j.1467-7660.1986.tb00231.x.

Geng, Y., and H. X. Zhao. 2009. "Industrial park management in the Chinese environment." J. Clean. Prod. 17 (14): 1289-1294. https:// doi.org/10.1016/j.jclepro.2009.03.009.

Giddings, B., B. Hopwood, and G. O'Brien. 2002. "Environment, economy and society: Fitting them together into sustainable development." Sustainable Dev. 10 (4): 187-196. https://doi.org/10.1002/sd.199.

Goodland, R., and H. Daly. 1996. "Environmental sustainability: Universal and non-negotiable.” Ecol. Appl. 6 (4): 1002-1017. https://doi.org/10 $.2307 / 2269583$. 
Gu, C. L., Y. Li, and S. S. Han. 2015. "Development and transition of small towns in rural China." Habitat Int. 50: 110-119. https://doi.org/10.1016 /j.habitatint.2015.08.017.

Guo, X. X., X. L. Xia, X. L. Zhang, and C. Feng. 2014. "Comprehensive evaluation analysis of small towns development level in China's different regions." [In Chinese.] Areal Res. Dev. 33 (5): 50-54. https://doi.org /10.3969/j.issn.1003-2363.2014.05.010.

Gustavson, K. R., S. C. Lonergan, and H. J. Ruitenbeek. 1999. "Selection and modeling of sustainable development indicators: A case study of the Fraser River Basin, British Columbia." Ecol. Econ. 28 (1): 117 132. https://doi.org/10.1016/S0921-8009(98)00032-9.

Hao, Y., M. R. Su, L. X. Zhang, Y. P. Cai, and Z. F. Yang. 2015. "Integrated accounting of urban carbon cycle in Guangyuan, a mountainous city of China: The impacts of earthquake and reconstruction." J. Clean. Prod. 103: 231-240. https://doi.org/10.1016/j.jclepro.2014 .05 .091 .

He, S., C. Fang, and W. A. Zhang. 2017. "Geospatial analysis of multi-scalar regional inequality in China and in metropolitan regions." Appl. Geogr. 88: 199-212. https://doi.org/10.1016/j.apgeog.2017.08.017.

Hirschman, A. O. 1958. The strategy of economic development. New Haven, CT: Yale University Press.

Huang, J. X., and Y. Ye. 2004. "On the index system design of the sustainable development of the small towns in China." [In Chinese.] Sci. Tech. Prog. Policy 21 (5): 23-25. https://doi.org/10.3969/j.issn.1001-7348 2004.05.008.

Hwang, C. L., and K. Yoon. 1981. "Methods for multiple attribute decision making." In Vol. 186 of Lecture Notes in Economics and Mathematical Systems, edited by Y. Shi, S. Y. Wang, G. Kou, J. Wallenius, 58-191. Berlin: Springer.

Jolliffe, I. 2011. Principal component analysis. New York: Springer.

Kaiser, H. F. 1960. "The application of electronic computers to factor analysis." Educ. Psychol. Meas. 20 (1): 141-151. https://doi.org/10.1177 /001316446002000116.

Kanbur, R., and A. J. Venables. 2005. Rising spatial disparities and development Helsinki. Helsinki, Finland: United Nations University.

Ke, S., and E. Feser. 2010. "Count on the growth pole strategy for regional economic growth? Spread-backwash effects in Greater Central China.” Reg. Stud. 44 (9): 1131-1147. https://doi.org/10.1080 /00343400903373601.

Krugman, P. 1999. "The role of geography in development." Int. Reg. Sci. Rev. 22 (2): 142-161. https://doi.org/10.1177/016001799761012307.

Li, Y., and Y. H. D. Wei. 2010. "The spatial-temporal hierarchy of regional inequality of China." Appl. Geogr. 30 (3): 303-316. https://doi.org/10 .1016/j.apgeog.2009.11.001.

Liang, H. 2009. "Coupling relationships of land use benefits in Shenzhen China.” Int. J. Cons. Manage. 9 (2): 33-43. https://doi.org/10.1080 $/ 15623599.2009 .10773127$.

Lin, G. C. S., and L. J. C. Ma. 1994. "The role of towns in Chinese regional-development: The case of Guangdong Province." Int. Reg. Sci. Rev. 17 (1): 75-97. https://doi.org/10.1177/016001769401700104.

Litwack, J. M., and Y. Qian. 1998. "Balanced or unbalanced development: special economic zones as catalysts for transition." J. Comp. Econ. 26 (1): 117-141. https://doi.org/10.1006/jcec.1997.1502.

Liu, J., and G. Li. 2019. "Comprehensive benefit evaluation on urban village micro-transformation based on extension matter-element model." Int. J. Constr. Manage. https://doi.org/10.1080/15623599.2019 .1569817.

Liu, Y., and Y. Li. 2017. "Revitalize the world's countryside." Nature 548 (7667): 275-277. https://doi.org/10.1038/548275a.

Long, H., Y. Li, Y. Liu, M. Woods, and Z. Jian. 2012. "Accelerated restructuring in rural China fueled by 'increasing vs. decreasing balance' landuse policy for dealing with hollowed villages." Land Use Policy 29 (1): 11-22. https://doi.org/10.1016/j.landusepol.2011.04.003.

Lu, F., and J. Qian. 2007. "Reflection on the ecological development of cities in western mountainous region." [In Chinese.] Planners 23 (12): 92-94. https://doi.org/10.3969/j.issn.1006-0022.2007.12.016.

Lu, K. J., Y. L. Liu, and K. Guan. 2001. "Study on the system of evaluating of factors in small town construction." [In Chinese.] Urban Stud. 8 (5): 69-72. https://doi.org/10.3969/j.issn.1006-3862.2001.05.015.
Luo, X. L., J. X. Zhang, and X. F. Jiang. 2000. "The development of small towns and its reflections in the change Southern Jiangsu Model." [In Chinese.] Urban Plan. Forum. 23 (5): 26-27. https://doi.org/10.3969 /j.issn.1000-3363.2000.05.007.

Ma, L. J. C., and M. Fan. 1994. "Urbanisation from below: The growth of towns in Jiangsu, China." Urban Stud. 31 (10): 1625-1645. https://doi .org/10.1080/00420989420081551.

Ma, L. J. C., and C. S. Lin. 1993. "Development of towns in China: A casestudy of Guangdong Province." Popul. Dev. Rev. 19 (3): 583-606. https://doi.org/10.2307/2938467.

Ma, X., Z. Wang, and J. Xu. 2004. "Study on differentiation of scale and economical development of small town in Jiangsu province." [In Chinese.] Econ. Geogr. 24 (2): 231-235. https://doi.org/10.3969/j.issn .1000-8462.2004.02.019.

Mao, H., and X. Zhang. 2009. "Study on construction planning of mountainous towns based on landscape ecology." [In Chinese.] J. Mt. Sci. 27 (5): 612-617. https://doi.org/10.3969/j.issn.1008-2786.2009.05.015.

MOHURD (Ministry of Housing and Urban-Rural Development). 2016. China urban-rural construction statistical yearbook. Beijing: MOHURD.

Myrdal, G. 1957. Economic theory and under-developed regions. New York: Harper \& Brothers Publishers.

Niemeijer, D., and R. S. de Groot. 2008. "A conceptual framework for selecting environmental indicator sets." Ecol. Indic. 8 (1): 14-25. https:// doi.org/10.1016/j.ecolind.2006.11.012.

Nurkse, R. 1953. Problems of capital formation in underdeveloped countries. Oxford, UK: Basil Blackwell.

Onishi, T. 1994. "A capacity approach for sustainable urban development: An empirical study." Reg. Stud. 28 (1): 39-51. https://doi.org/10.1080 /00343409412331348056.

Parris, T. M., and R. W. Kates. 2003. "Characterizing and measuring sustainable development." Annu. Rev. Environ. Resour. 28 (1): 559-586. https://doi.org/10.1146/annurev.energy.28.050302.105551.

Pearce, D. W., and J. J. Warford. 1993. World without end: Economics, environment, and sustainable development. New York: Oxford University Press.

Perroux, F. 1950. "Economic space: Theory and application." Q. J. Econ. 64 (1): 89-104. https://doi.org/10.2307/1881960.

Qian, J., D. Feng, and H. Zhu. 2012. "Tourism-driven urbanization in China's small town development: A case study of Zhapo Town, 1986-2003.” Habitat Int. 36 (1): 152-160. https://doi.org/10.1016/j .habitatint.2011.06.012.

Qian, Z., and J. H. Xue. 2017. "Small town urbanization in Western China: Villager resettlement and integration in Xi'an." Land Use Policy 68 : 152-159. https://doi.org/10.1016/j.landusepol.2017.07.033.

Repetti, A., and G. Desthieux. 2006. "A relational indicatorset model for urban land-use planning and management: Methodological approach and application in two case studies." Landscape Urban Plann. 77 (12): 196-215. https://doi.org/10.1016/j.landurbplan.2005.02.006.

Robert, K. W., T. M. Parris, and A. A. Leiserowitz. 2005. "What is sustainable development? Goals, indicators, values, and practice." Environ. Sci. Policy Sustainable Dev. 47 (3): 8-21. https://doi.org/10.1080 /00139157.2005.10524444.

Rostow, W. W. 1956. "The take-off into self-sustained growth." Econ. $J$. 66 (261): 25-48. https://doi.org/10.1007/978-1-349-15452-4_8.

Roy, M. 2009. "Planning for sustainable urbanisation in fast growing cities: Mitigation and adaptation issues addressed in Dhaka, Bangladesh." Habitat Int. 33 (3): 276-286. https://doi.org/10.1016/j.habitatint.2008 .10 .022 .

Shen, J. F., Z. Q. Feng, and K. Y. Wong. 2006. "Dual-track urbanization in a transitional economy: The case of Pearl River Delta in South China." Habitat Int. 30 (3): 690-705. https://doi.org/10.1016/j.habitatint.2005 .04 .003 .

Shen, J. F., K. Y. Wong, and Z. Q. Feng. 2002. "State-sponsored and spontaneous urbanization in the Pearl River Delta of South China, 1980 1998." Urban Geogr. 23 (7): 674-694. https://doi.org/10.2747/0272 $-3638.23 .7 .674$

Shen, L.-Y., J. J. Ochoa, M. N. Shah, and X. L. Zhang. 2011. "The application of urban sustainability indicators - A comparison between 
various practices." Habitat Int. 35 (1): 17-29. https://doi.org/10.1016/j .habitatint.2010.03.006.

Shen, L. Y., Y. T. Ren, N. Xiong, H. Li, and Y. Chen. 2018. "Why small towns cannot share the benefits of urbanization in China?" J. Clean. Prod. 174: 728-738. https://doi.org/10.1016/j.jclepro.2017.10.150.

Shen, L. Y., and J. Y. Zhou. 2014. "Examining the effectiveness of indicators for guiding sustainable urbanization in China." Habitat Int. 44: 111-120. https://doi.org/10.1016/j.habitatint.2014.05.009.

Shi, Y. 2002. "The analysis on the mistakes in the rural small town development." [In Chinese.] City Plann. Rev. 26 (4): 27-31. https://doi.org /10.3321/j.issn:1002-1329.2002.04.007.

Silva, J. A. 2007. "Trade and income inequality in a less developed country: The case of Mozambique." Econ. Geogr. 83 (2): 111-136. https:// doi.org/10.1111/j.1944-8287.2007.tb00339.x.

Song, G.-K., and G.-S. Li. 2015. "Development of key small towns and urbanization - reflection on the theory "uneven spatial development"." [In Chinese.] J. Lanzhou Univ. (Soc. Sci.) 43 (5): 22-30. https://doi org/10.3969/j.issn.1000-2804.2015.05.003.

Spenceley, A., and D. Meyer. 2012. "Tourism and poverty reduction: Theory and practice in less economically developed countries." $J$ Sustainable Tour. 20 (3): 297-317. https://doi.org/10.1080/09669582 .2012.668909

State Council of China. 1984. Report on Adjusting the Standards for Building Towns.

Tan, K. C. 1986. "Revitalized small towns in China." Geogr. Rev. 76 (2): 138-148. https://doi.org/10.2307/214620.

Tan, M. H., and X. B. Li. 2013. "The changing settlements in rural areas under urban pressure in China: Patterns, driving forces and policy implications." Landscape Urban Plann. 120: 170-177. https://doi.org/10 .1016/j.landurbplan.2013.08.016.

UNSIAP (United Nations Statistical Institute for Asia and Pacific). 2007. "Building administrative data systems for statistical purposes-addressing training issues and needs of countries." In Inception/Regional Workshop on reta6356: Improving Administrative Data Sources for the Monitoring of the mdg Indicators. 26. Bangkok, Thailand: UNSIAP.

Wang, D. 1999. "Socioeconomic characteristics of rural urbanization in Southern Jiangsu, China.” Int. J. Soc. Econ. 26 (1/2/3): 290-297. https://doi.org/10.1108/03068299910229703.

Wang, Y.-J., and H.-S. Lee. 2007. "Generalizing TOPSIS for fuzzy multiple-criteria group decision-making." Comput. Math. Appl. 53 (11): 1762-1772. https://doi.org/10.1016/j.camwa.2006.08.037.

WCED (World Commission on Environment and Development). 1987. Our common future. New York: Oxford University Press.

Wei, Y. D. 2015. "Spatiality of regional inequality." Appl. Geogr. 61: 1-10. https://doi.org/10.1016/j.apgeog.2015.03.013.
Wei, Y. D., H. Li, and W. Yue. 2017. "Urban land expansion and regional inequality in transitional China." Landsc. Urban Plan. 163: 17-31. https://doi.org/10.1016/j.landurbplan.2017.02.019.

Williamson, J. G. 1965. "Regional inequality and the process of national development." Econ. Dev. Cult. Change 13 (2): 1-84. https://doi.org 10.1086/450136.

Wold, S., K. Esbensen, and P. Geladi. 1987. "Principal component analysis." Chemom. Intell. Lab. Syst. 2 (1-3): 37-52. https://doi.org/10.1016 /0169-7439(87)80084-9.

Wong, K. Y., J. F. Shen, Z. Q. Feng, and C. L. Gu. 2003. "An analysis of dual-track urbanisation in the Pearl River Delta since 1980." Tijdschr. Econ. Soc. Geogr. 94 (2): 205-218. https://doi.org/10.1111/1467 -9663.00249 .

WRI/IUCN (World Resources Institute, World Conservation Union, International Union for Conservation of Nature). 1992. Global biodiversity strategy: Guidelines for action to save, study, and use earth's biotic wealth sustainably and equitably. Washington, DC: WRI.

Xu, J., D. Q. Yi, X. S. Yi, M. Cui, and Z. Song. 2013. "Study on the development strategy of small towns in Chongqing under the background of new-type urbanization." [In Chinese.] In China Annual National Planning Conf. 1-19. Beijing, China: UPSC.

Yang, C., and H. F. Liao. 2010. "Industrial agglomeration of Hong Kong and Taiwanese manufacturing investment in China: A town-level analysis in Dongguan." Ann. Reg. Sci. 45 (3): 487-517. https://doi.org/10 1007/s00168-009-0305-8.

Yao, G. R., and H. L. Xie. 2016. "Rural spatial restructuring in ecologically fragile mountainous areas of southern China: A case study of Changgang Town, Jiangxi Province.” J. Rural Stud. 47: 435-448. https://doi.org/10.1016/j.jrurstud.2016.07.014.

Yuan, Z., and Z. Yang. 2004. "The research on small town's zone difference of China." [In Chinese.] Econ. Geogr. 24 (3): 361-363. https:// doi.org/10.3969/j.issn.1000-8462.2004.03.017.

Zhang, H. Z., T. H. Chi, J. R. Fan, K. H. Hu, and L. Peng. 2015. "Spatial analysis of wenchuan earthquake-damaged vegetation in the mountainous basins and its applications." Remote Sens. 7 (5): 5785-5804. https:// doi.org/10.3390/rs70505785.

Zhang, P., Q. S. Yang, and H. Wang. 2011. "Development mode of small towns in integrated region of Changchun and Jilin based on urban-rural integration." [In Chinese.] Econ. Geogr. 31 (4): 599-602. https://doi .org/10.15957/j.cnki.jjd1.2011.04.012.

Zhang, R. H., X. Liu, G. C. Heathman, X. Y. Yao, X. L. Hu, and G. C. Zhang. 2013. "Assessment of soil erosion sensitivity and analysis of sensitivity factors in the Tongbai-Dabie mountainous area of China." CATENA 101: 92-98. https://doi.org/10.1016/j.catena.2012 .10.008. 